\title{
Upregulation of a tonoplast-localized cytochrome P450 during petal senescence in Petunia inflata Yan $\mathrm{Xu}^{1,2}$, Hiroyuki Ishida ${ }^{1,3}$, Daniel Reisen ${ }^{1}$ and Maureen R Hanson ${ }^{* 1}$
}

Address: ${ }^{1}$ Department of Molecular Biology and Genetics, Biotechnology Building, Cornell University, Ithaca, NY 14853, USA, ${ }^{2}$ Current address: New England BioLabs, Inc., 240 County Road, Ipswich, MA 01938, USA and ${ }^{3}$ Laboratory of Plant Nutrition and Function, Department of Applied Plant Science, Tohoku University, Tsutsumidori-Amamiyamachi 1-1, Sendai 981-8555, Japan

Email: YanXu - xuy@neb.com; Hiroyuki Ishida - hiroyuki@biochem.tohoku.ac.jp; Daniel Reisen - dr237@cornell.edu; Maureen R Hanson*-mrh5@cornell.edu

* Corresponding author

Published: 13 April 2006

BMC Plant Biology 2006, 6:8 doi:10.1 186/147/-2229-6-8
Received: 05 January 2006

Accepted: 13 April 2006

This article is available from: http://www.biomedcentral.com/l47/-2229/6/8

(C) 2006 Xu et al; licensee BioMed Central Ltd.

This is an Open Access article distributed under the terms of the Creative Commons Attribution License (http://creativecommons.org/licenses/by/2.0), which permits unrestricted use, distribution, and reproduction in any medium, provided the original work is properly cited.

\begin{abstract}
Background: Gene expression in Petunia inflata petals undergoes major changes following compatible pollination. Severe flower wilting occurs reproducibly within 36 hours, providing an excellent model for investigation of petal senescence and programmed cell death. Expression of a number of genes and various enzyme activities involved in the degradation and remobilization of macromolecules have been found to be upregulated during the early stages of petal senescence.
\end{abstract}

Results: By performing differential display of cDNAs during Petunia inflata petal senescence, a highly upregulated gene encoding a cytochrome P450 was identified. Analysis of the complete cDNA sequence revealed that the predicted protein is a member of the CYP74C family (CYP74C9) and is highly similar to a tomato CYP74C allene oxide synthase (AOS) that is known to be active on 9-hydroperoxides. Cloning of the petunia genomic DNA revealed an intronless gene with a promoter region that carries signals found in stress-responsive genes and potential binding sites for Myb transcription factors. Transcripts were present at detectable levels in root and stem, but were 40 times more abundant in flowers 36 hours after pollination. Ethylene and jasmonate treatment resulted in transitory increases in expression in detached flowers. A protein fusion of the CYP74C coding region to a C-terminal GFP was found to be located in the tonoplast.

Conclusion: Though oxylipins, particularly jasmonates, are known to be involved in stress responses, the role of other products of CYP74 enzymes is less well understood. The identification of a CYP74C family member as a highly upregulated gene during petal senescence suggests that additional products of fatty acid metabolism may play important roles during programmed cell death. In contrast to the chloroplast localization of AOS proteins in the CYP74A subfamily, GFP fusion data indicates that the petunia CYP74C9 enzyme is in the tonoplast. This result suggests that the highly similar CYP74C enzymes that have been identified in two other Solanaceous plants may also be associated with the vacuole, an organelle known to have a prominent role in programmed cell death. 


\section{Background}

Plant cell death occurs during the hypersensitive response [1,2], response to environmental stress [3], senescence [4], and the development of plant tissues and organs $[3,5]$. Among these phenomena, petal senescence is of interest both because of its importance to the horticultural industry as well as a model for programmed cell death (PCD). Petal senescence shares a hallmark feature of PCD, namely DNA fragmentation [6,7]. In contrast, an early apoptotic event common in mammalian cells, the relocation of cytochrome $\mathrm{c}$ from the mitochondrial membrane space into the cytosol, was not detected as a signal for wilting of petunia petal tissues [6]. Evidently some plant death processes do not necessarily require cytochrome c release as a signal. In Arabidopsis protoplasts, when death was induced by $\mathrm{C} 2$ ceramide, loss of mitochondrial membrane potential and cytochrome c release were observed early in the death process. However, when protoporphyrin IX was used as the induction signal, although a decrease in membrane potential occurred, cytochrome c release was not observed until after the Arabidopsis protoplasts had died [8]. In most other studies of various types of plant PCD, cytochrome c release was observed during PCD, for example, in stressed cultured cells $[9,10]$, tapetal cells [11], proteasome-inhibited epidermal cells [12], and toxin-treated mesophyll cells [13].

Subtractive cloning and differential display have been used to identify a number of genes that are highly induced during senescence. Consistent with the profound effect of ethylene on floral senescence in ethylene-sensitive flowers, petal wilting is preceded by the up-regulation of both ACC synthase and ACC oxidase in both Petunia and carnation $[14,15]$. Most other genes up-regulated during petal senescence that have been identified so far encode enzymes involved in the degradation and remobilization of macromolecules (reviewed in $[5,16]$ ), including a thiol protease [17], acyl-CoA oxidase [18], glutathione-S-transferase [19], DNases and RNases [6,20,21], and lipoxygenases [22,23]. Other upregulated genes that have been identified have unknown functions, such as a calmodulinbinding protein [24] and a zinc-finger DNA-binding protein [25].

In the self-incompatible species Petunia inflata, petal senescence can be triggered reproducibly by compatible pollination, with clear wilting symptoms appearing at 36 hours after compatible pollination (HACP) [6]. This pollination-induced petal senescence not only minimizes environmental influences, but also provides an inducible system to clone and investigate up-regulated genes associated with petal cell death. Using the technique of differential display during pollination-induced petal senescence, an upregulated gene with similarity to the CYP74C subfamily of cytochrome P450s was identified. Sequence analysis indicates the predicted protein (designated CYP74C9 by the P450 nomenclature committee, identified here as PiCYP74C9) is most related to an unusual tomato allene oxide synthase that preferentially metabolizes 9-hydroperoxides [26]. While some AOS proteins have been localized to the chloroplast envelope, analysis of transgenic plants carrying PiCyP74C9 fused to GFP indicate that the $P$. inflata protein is located in the tonoplast.

\section{Results \\ Isolation of Psr genes}

Morphologically, programmed cell death (PCD) can be divided into two distinct stages [27], condemned/latent stage and execution stage. In the condemned stage, no obvious morphological changes are visible and the duration is quite variable. At 24 hours after compatible selfpollination (HACP), the $P$. inflata flowers appear quite normal but are condemned; at 36 hours the flowers are quite wilted [6]. To identify genes that are up-regulated during the condemned phase of petal senescence, differential display (DD) was used to compare mRNA expression profiles [28] from transcripts of young petals from flowers that just opened with those of senescing petals from flowers at 24 and 36 HACP. This comparison was to identify those genes which may be involved in early events (24 hours) during the condemned phase as well as gene involved in late events of senescence equivalent to the execution stage in apoptosis [6].

Fig. 1 shows examples of DD gels comparing mRNAs of petal tissues collected at the indicated time after pollination. On the 24 HACP DD gel, most transcripts showed similar levels of expression at 0 and 24 HACP (left panel). In contrast, the steady-state level of most mRNAs at 36 HACP is reduced compared to 0 HACP (right panel). This may be due to a decreased transcription rate or an increased RNA degradation. Differential bands were cloned into TA cloning vectors and used as probes to confirm increased expression at 36 hours on Northern blots.

Using a 1:1 ratio of mRNA from petals at $24 \mathrm{HACP}$ and 36 HACP, a cDNA library specific to the petal and enriched in senescence-related RNAs was constructed. The primary library was screened for the coding regions of Psr genes. Two independent clones contained a sequence similar to ACC oxidase, an enzyme involved in ethylene biosynthesis. Two other independent clones carried a sequence similar to a member of the plant CYP74 family, cytochrome P450s. These genes were termed petal senescence related (psr) genes, Psr1 (ACC oxidase) and Psr2 (encoding CYP74C9). 

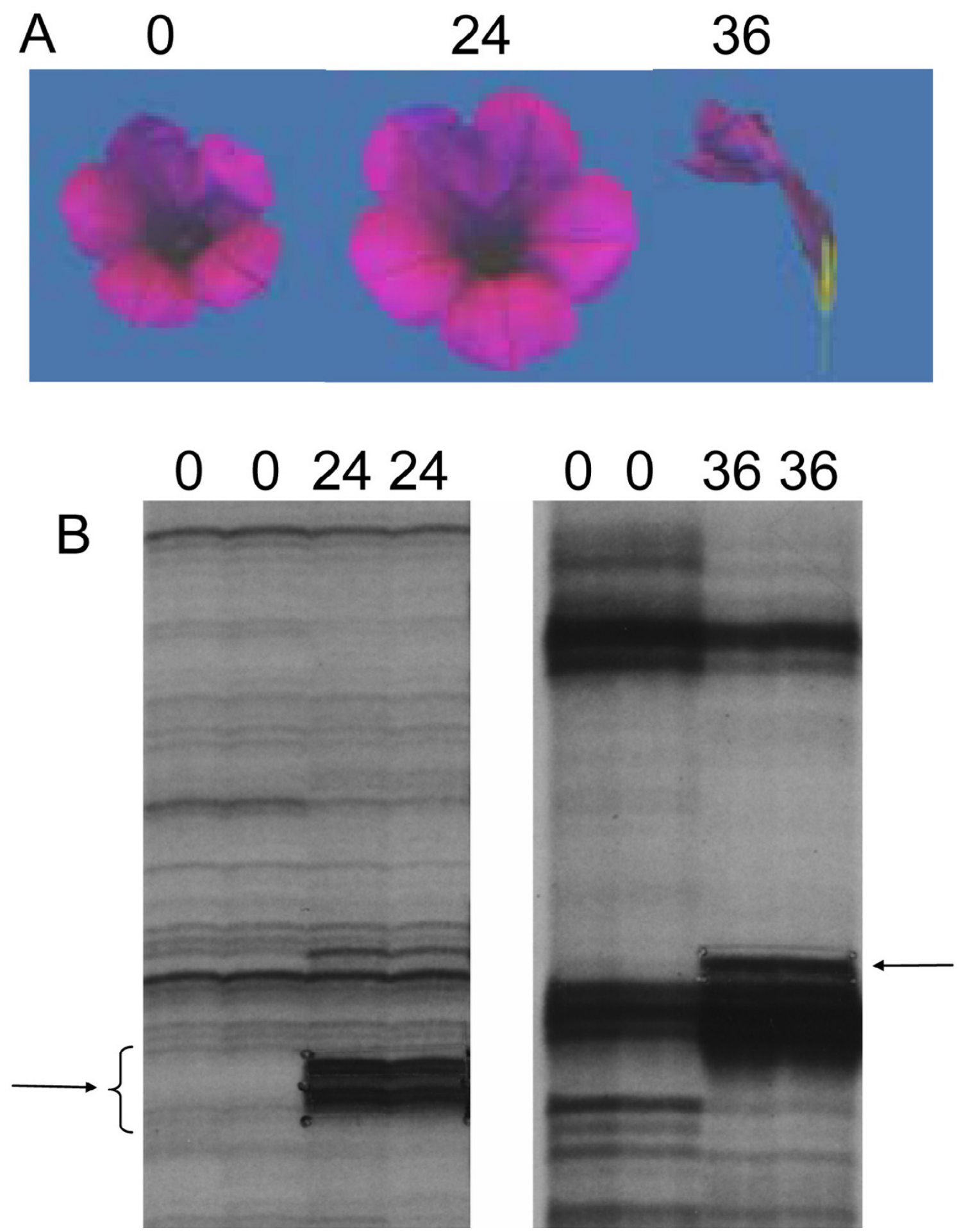

\section{Figure I}

Changes in floral morphology and RNA profiles at various hours after compatible pollination (HACP). (A) $P$. inflata flowers at 0, 24, and $36 \mathrm{HACP}$. (B) Comparison of expressed mRNAs in petal tissues by differential display (DD). Two different primer sets were used for the DD experiments shown. Left, a DD between 0 HACP and 24 HACP. Right, a DD between $0 \mathrm{HACP}$ and $36 \mathrm{HACP}$. Arrows indicate a few of the DD bands indicating upregulated transcripts during petal senescence. 


\section{Construction of full-length cDNA of Psr2 and characteristics of CYP74C9}

Several cDNA clones with partial coding regions were isolated for Psr2 by cDNA library screening. Two 3' end sequences have been identified, implying the existence of two polyadenylation sites, which are marked with arrows in Fig. 2. Surprisingly, the sequence isolated by DD is located in the 5' coding region between nucleotide 436 to

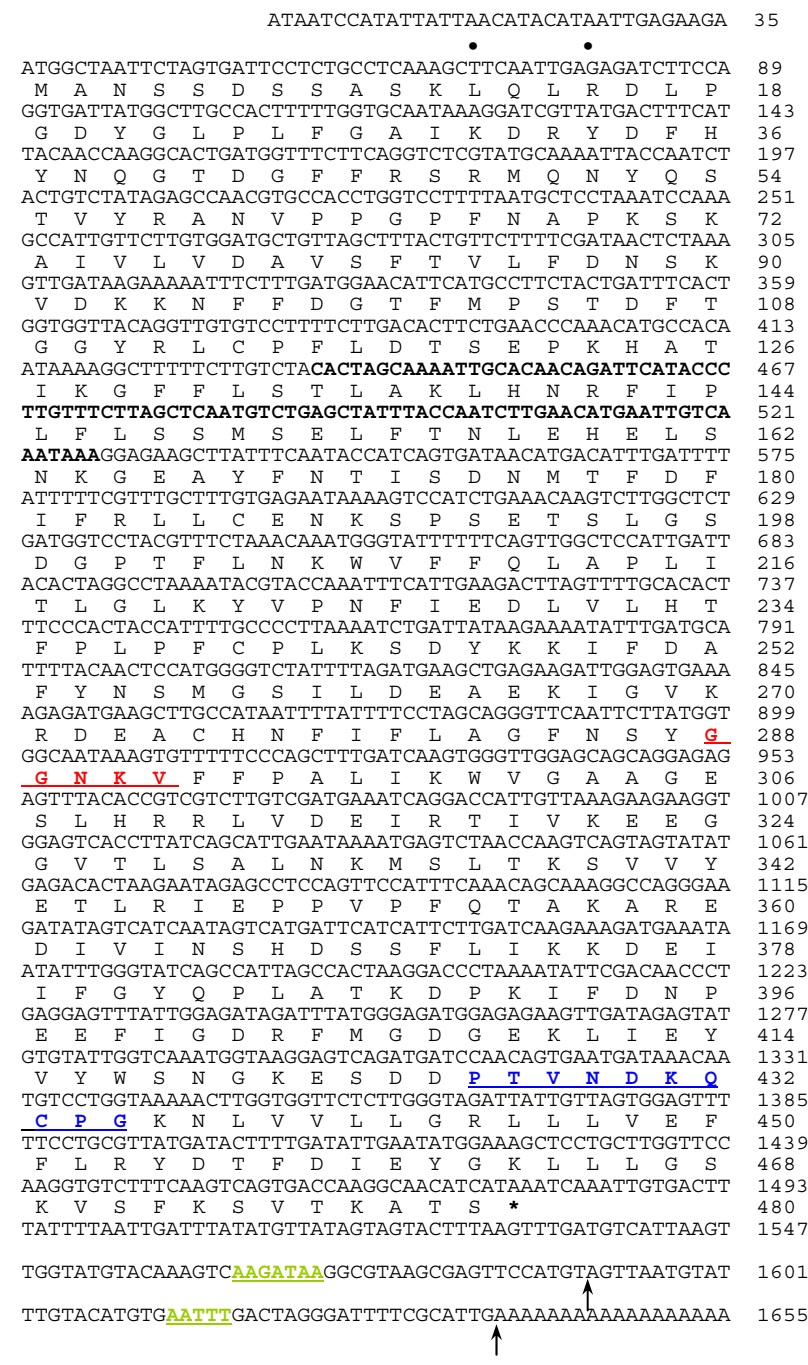

Figure 2

Nucleotide sequence of Psr2 cDNA [Genbank: DQ35 I288] with translation of coding region. The Ihelix (red), heme-binding (blue) region, and two potential polyadenylation signals (green) are underlined. Processing sites for polyadenylation are indicated by arrows. The sequence of the longest cDNA obtained is shown; other cDNAs exhibited polyadenylation at the first arrow. The stop codon is marked with an asterisk. In addition, two nonsense codons upstream from the initiating ATG are indicated by dots. The cDNA sequence obtained by DD is boldface.
527 (Fig. 2), which is probably due to the presence of an AT rich sequence (AAATAAA). In order to obtain the 5' sequence, a 5' RACE method [29] was used and extended the 5 ' sequence by 72 nucleotides (Fig. 2, nucleotides 1 to 72). The longest ORF encoded by Psr2 is 480 amino acids, which is preceded by two in-frame nonsense codons (Fig. 2).

The predicted protein product of Psr2 shows significant sequence identity to the P450 enzymes in the CYP74 subfamily (Fig. 3). Members of this family have been shown to function either as allene oxide synthase (AOS), hydroperoxide lyase (HPL), or divinyl ether synthase (DES) [30-32]. The predicted 480-amino-acid protein exhibits $68 \%$ identity and $86 \%$ similarity to a well-characterized 491 amino-acid tomato protein that has been shown to exhibit AOS activity on 9-hydroperoxides [26]. The predicted petunia protein contains a conserved PPGP tetrapeptide near the amino terminus (residue 62 to 65 , Fig. 3) that is also common in P450s, a membrane hinge that is known to be important for P450 stability and catalysis $[33,34]$. The unique feature of the CYP74 subfamily is the oxygen-binding pocket, the I-helix. In contrast to the consensus I-helix (GxxxT) in most P450s, the threonine residue is substituted with either isoleucine, alanine, or valine (GxxxI/A/V) (Fig. 4) in AOS, HPL, and DES enzymes. The presence of GxxxV in PiCYP74C9 indicates that the protein is a peroxide dehydrase rather than an oxygenase, consistent with the known properties of this cytochrome $\mathrm{P} 450$ subfamily. Three members of each group within the CYP74C family and the CYP74D family are compared in two conserved regions in Fig. 4. In the Ihelix region, the AOS group is more similar to the HPL group than to the DES group. In the heme binding region, the AOS group exhibits sequence similarities to both the DES and HPL groups (Fig. 4).

Phylogenetic analysis (Fig. 5) is consistent with the assignment of the Psr2 gene product as a CYP74C family member and with its likely activity as an allene oxide synthase operating on 9-hydroperoxides. This maximum parsimony analysis organizes the proteins as expected in the CYP74A, CYP74B, and CYP74D sub-families. The CYP74C members assort into two groups, comprised of those with HPL or AOS activities, with PiCYP74C9 clearly located with the proteins with known AOS activity (Fig. 5 ). The tree generated by nearest neighbor analysis is quite similar, also separating the AOS and HPL CYP74C members.

\section{Developmental and tissue-specific expression of Psr2}

Analysis of the time course of Psr2 expression shows that Psr2 mRNA is not detectable on RNA blots immediately after opening but is strongly up-regulated at 24 HACP (Fig. 6). The peak expression of Psr2 was at 36 HACP and 


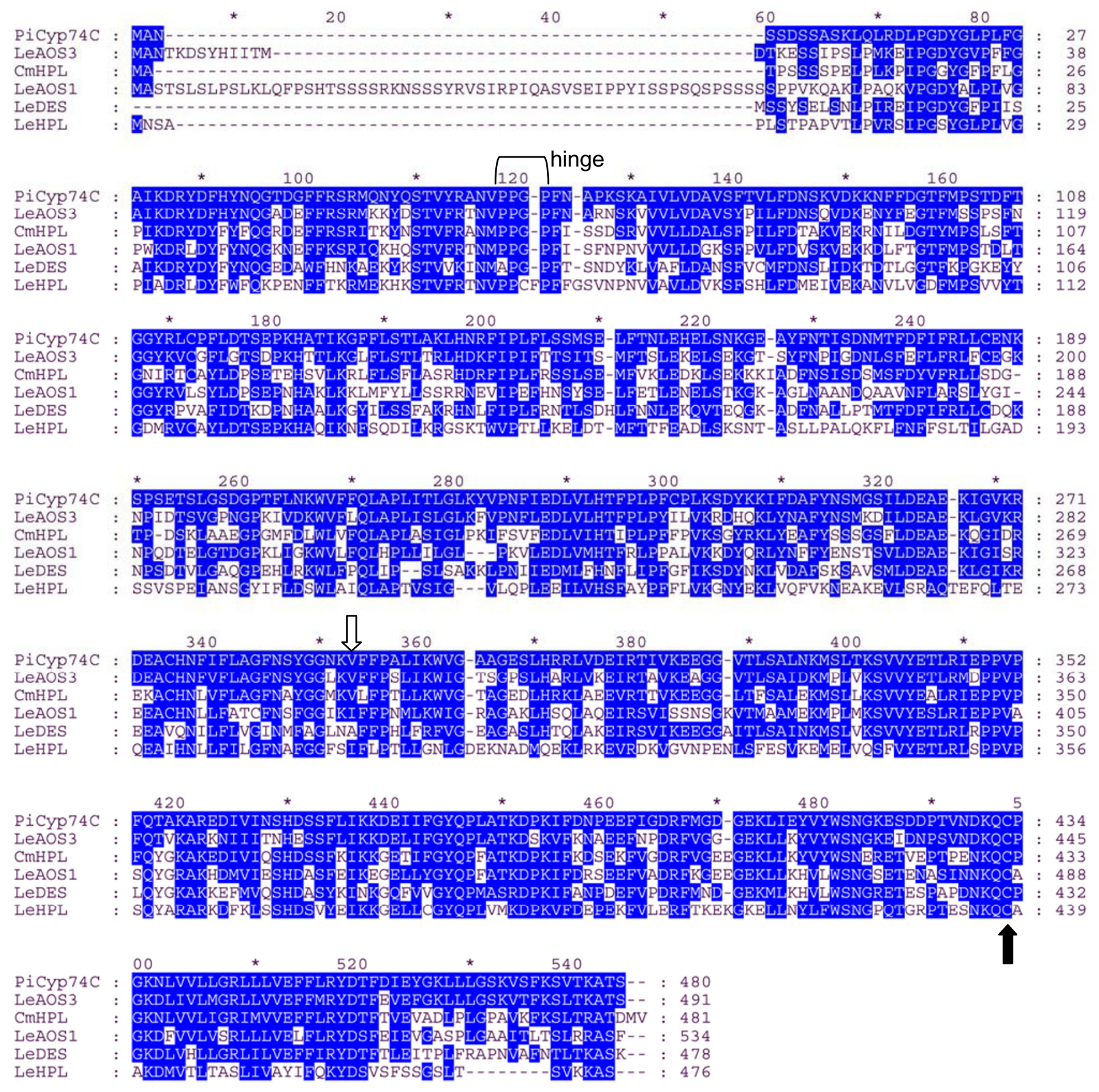

\section{Figure 3}

Comparison of amino acid sequences of PiCYP74C9 with other CYP74 family members. LeAOS3 [Genbank: $z$ AF454634], CmHPL [Genbank: ż AF081955], LeAOSI [Genbank: A]271093], LeDES [Genbank: AF3 175I5], LeHPL [Genbank: z AF230372], PiCYP74C9 [Genbank: z DQ35 I288]. Shading indicates amino acids identical or similar to residues in PiCYP74C9. Decoration near residue I20 indicates the PPGP membrane hinge. Hollow arrow indicates conserved I/A/V found in members of the CYP74 family. The conserved cysteine present in all P450s is indicated by the solid arrow.

then declined at 48 HACP. Psr 2 was also induced in senescing stamens and pistils at $36 \mathrm{HACP}$ and senescing petals of unpollinated flowers 6 days after opening (Fig.
7), suggesting that Psr2 may be useful as a molecular marker of floral senescence. 


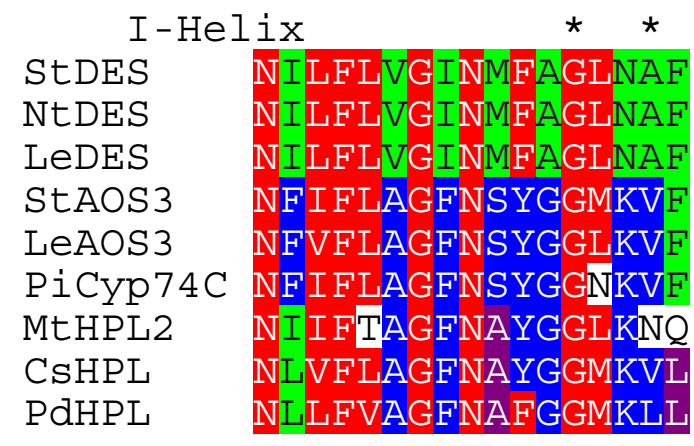

\begin{tabular}{ll}
\multicolumn{2}{c}{ Heme-Binding } \\
StDES & ENPAPDNKQCPGKDLVHLLG \\
NtDES & ENPAPDNKQCAGKDLVHLLG \\
LEDES & ESPAPDNKQCPGKDLVHLLG \\
StAOS3 & DNPTVNDKQCPGKDLIVLLG \\
LEAOS3 & DNPSVNDKQCPGKDLIVLMG \\
PiCYP74C & DDPTVNDKQCPGKNLVVLLG \\
MtHPL2 & EEPSVGNKQCPGKNLVVLLC \\
CSHPL & VEPTAENKQCPGKNLVVMMG \\
PdHPL & DHPTAENKQCPGKDLVVLIS
\end{tabular}

\section{Figure 4}

Comparison of conserved domains of cytochrome P450s, the I-helix and heme-binding region, in the CYP74C9 subfamily. Shading: red, conserved in most sequences; green, conserved in DES group or DES plus others; blue, conserved in AOS group or AOS plus HPL; black, conserved in HPL group. Asterisks indicate the $G$ and I/A/V of the I-helix. Arrow indicates the conserved P450 cysteine.

Among the different tissues tested, Psr2 was expressed at low levels constitutively in the root and stem and at much lower levels in other young tissues, including healthy leaves and tissues from unopened flowers (Fig. 7). A densitometry measurement shows that the induced level of Psr 2 mRNA in the pollinated petals at 36 HACP is about 40-fold higher than the constitutive level in either root or stem (Fig. 7). Since treatments with ethylene and jasmonates have been shown to accelerate petal senescence in P. hybrida [35,36], ethephon or MEJA was applied to detached flowers of $P$. inflata. Ethephon is a commonly used substitute for ethylene and easily converted into ethylene within plant cells [37]. In the presence of $1 \mathrm{mM}$ ethephon, $P$. inflata flowers wilted within 24 hours (data not shown), whereas with simple distilled water treatment, detached flowers could last more than 6 days (data not shown). MEJA treatment seemed to promote a change in petal color rather than physical wilting (data not shown). Both ethephon treatment and MEJA treatment (Fig. 7) caused a transient increase in $P s r 2$ transcripts in detached flowers.

\section{Characterization of Psr2 gene organization and promoter elements}

A DNA blot probed with a Psr2 cDNA under stringent washing conditions showed that Psr2 is a single copy gene (Fig. 8), as is the highly similar tomato gene encoding LeAOS3 [26]. However, additional faint bands appeared after long exposure, suggesting the presence of similar sequences in Petunia (data not shown). By screening a $P$. inflata genomic library [38], the promoter region and the genomic copy of Psr2 were isolated. In the genomic clone with the longest $5^{\prime}$ sequence, the upstream regulatory region is 2335 bp (Fig. 9). A CCAAT box is located at -230 to -226 and a TATA box is at -33 to -22 . Other cis-elements include a GCC box which may be ethylene responsive $[39,40]$, three TCA motifs (common in stress-inducible genes [41]), and several potential binding sites for Myb transcription factors including maize $\mathrm{P}$ and Petunia petal epidermis-specific Myb.Ph3 [42,43]. The putative transcription start site $(+1)$ is in agreement with both the plant consensus start sequence [44] and the sequence obtained from the 5' RACE (Fig. 9). The P. inflata Psr2 gene does not have introns. In the transcribed region, there is only one nucleotide difference between the Psr 2 genomic clone and the cDNA clone we sequenced. At position 3153 there is a $\mathrm{T}$ in the genomic sequence and a $\mathrm{C}$ in the cDNA sequence; because it is in the third position of the codon, the predicted amino acid sequence is not affected.

\section{Cellular localization of PiCYP74C9}

PiCYP74C9 lacks any defined targeting signal; analysis by a variety of web-based localization informatics programs gave inconclusive and contradictory results. To investigate the location of PiCYP74C9, the full coding region was fused in-frame to an enhanced GFP [45] and a strong promoter [46] and introduced into Nicotiana tabacum by Agrobacterium-mediated transformation.

A number of transgenic tobacco plants were identified that express the fusion protein at relatively high levels, according to immunoblot analysis with anti-GFP antibody (data not shown). All transgenic plants exhibited normal morphology and fertility. Microscopic analysis of transformed cells indicated that the signal was found in the tonoplast membrane (Fig. 10), as images were comparable to those obtained with a known tonoplast aquaporin/GFP fusion [47]. Images of isolated vacuoles verified the localization as in the tonoplast membrane (Fig. 10).

Because the GFP fluorescence signal was relatively weak, despite readily detectable GFP by immunoblot analysis of total leaf extracts, we considered the possibility that nonfluorescent GFP might be located in additional subcellular organelles, especially since certain AOS enzymes are known to be located in plastids [48-50]. We fractionated 


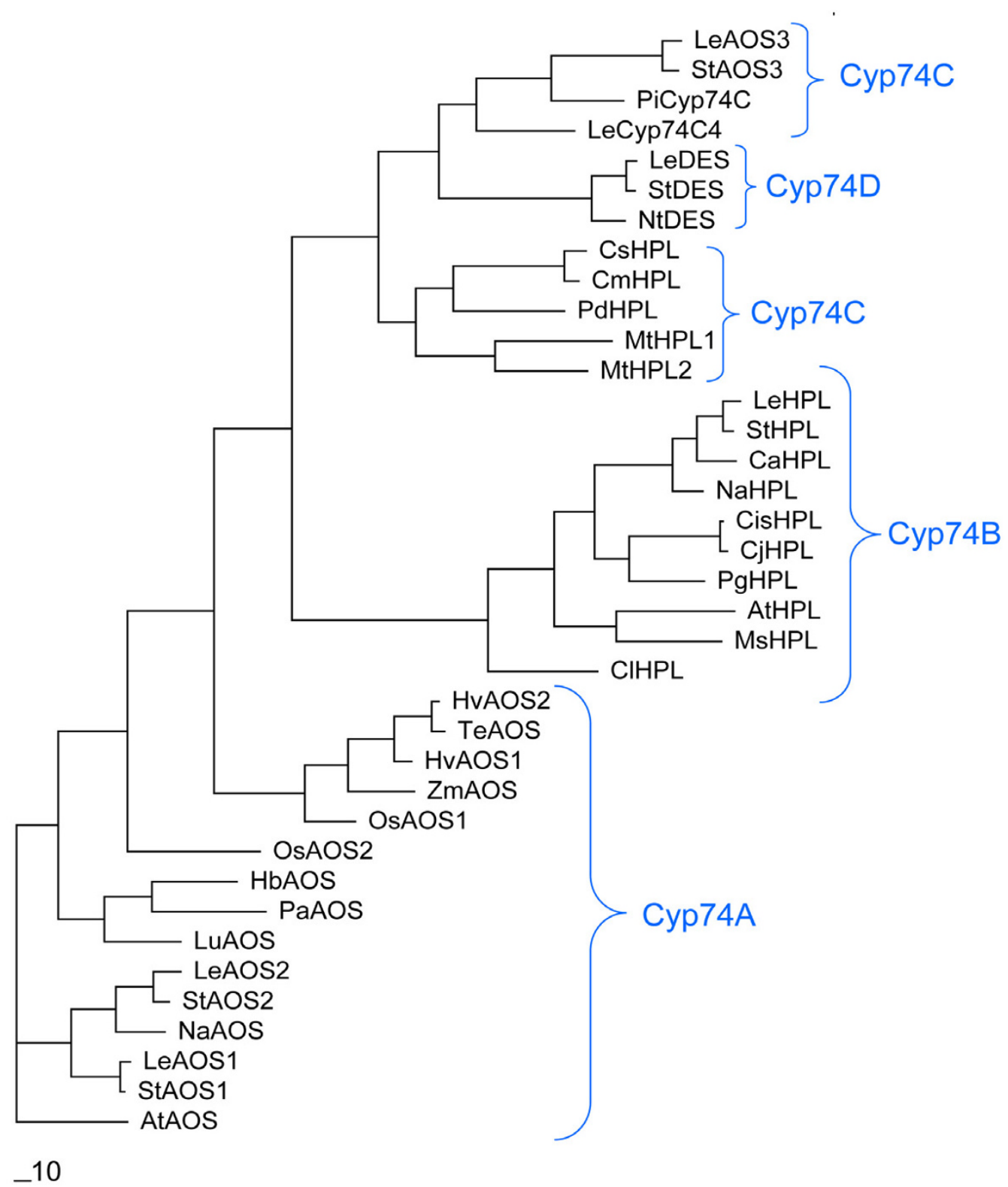

\section{Figure 5}

Phylogenetic analysis of members of the cytochrome P450 74C family. PAUP*4.0bI0 [84] was used to construct a maximum parsimony tree of 37 CYP74 P-450s, with branch swapping performed by tree bisection-reconnection (TBR). AtAOS [Genbank: Y 12636], AtHPL [Genbank: AF087932], CaHPL [Genbank: z U5 I674], CisHPL [Genbank: AY242385], CjHPL [Genbank: AB077765], CIHPL [Genbank: żAY703450, CmHPL [Genbank: z AF08I 955], CsHPL [Genbank: ż AF2298I I], HbAOS [Genbank: AY5I4020], HvAOSI [Genbank: A/250864], LeAOSI [Genbank: A/271093], LeAOS2 [Genbank: ż AF23037I], LeAOS3 [AF454634], LeCYP74C4 [Genbank: AF461042], LeDES [Genbank: AF3175I 5], LeHPL [Genbank: zz AF230372],

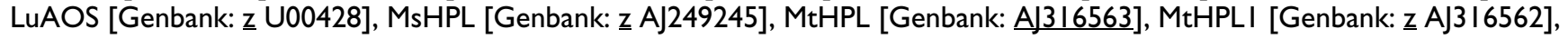
MtHPL2 [Genbank: AJ316563], NaAOS [Genbank: AJ295274], NaHPL [Genbank: AJ4I4400], NtDES [Genbank: AF070976], PaAOS [Genbank: X78|66], OsAOSI [Genbank: AY055775], OsAOS2 [Genbank: ABI 16527], PdHPL [Genbank: AJ578748], PgHPL [Genbank: AF239670], PiCYP74C9 [Genbank: z DQ35 I 288], StAOSI [Genbank: AJ457080], StAOS2 [Genbank: A]45708I], StAOS3 [Genbank: AJ868542], StDES [Genbank: AJ30954I], StHPL [Genbank: AJ310520], TeAOS [Genbank: zz AY 196004], ZmAOS [Genbank: AY488I35]. At: Arabidopsis; Ca, pepper; Cis, orange; Cj, rough lemon; Cm, muskmelon; Cs, cucumber; Hv, barley; Le: tomato; Lu, flax; Ms, alfalfa; Mt, barrel medic; $\mathrm{Nt}$, $\mathrm{Na}$, tobacco; Os, rice; $\mathrm{Pa}$, guayule; $\mathrm{Pg}$, guava; $\mathrm{Pi}$, Petunia inflata; St, potato. 


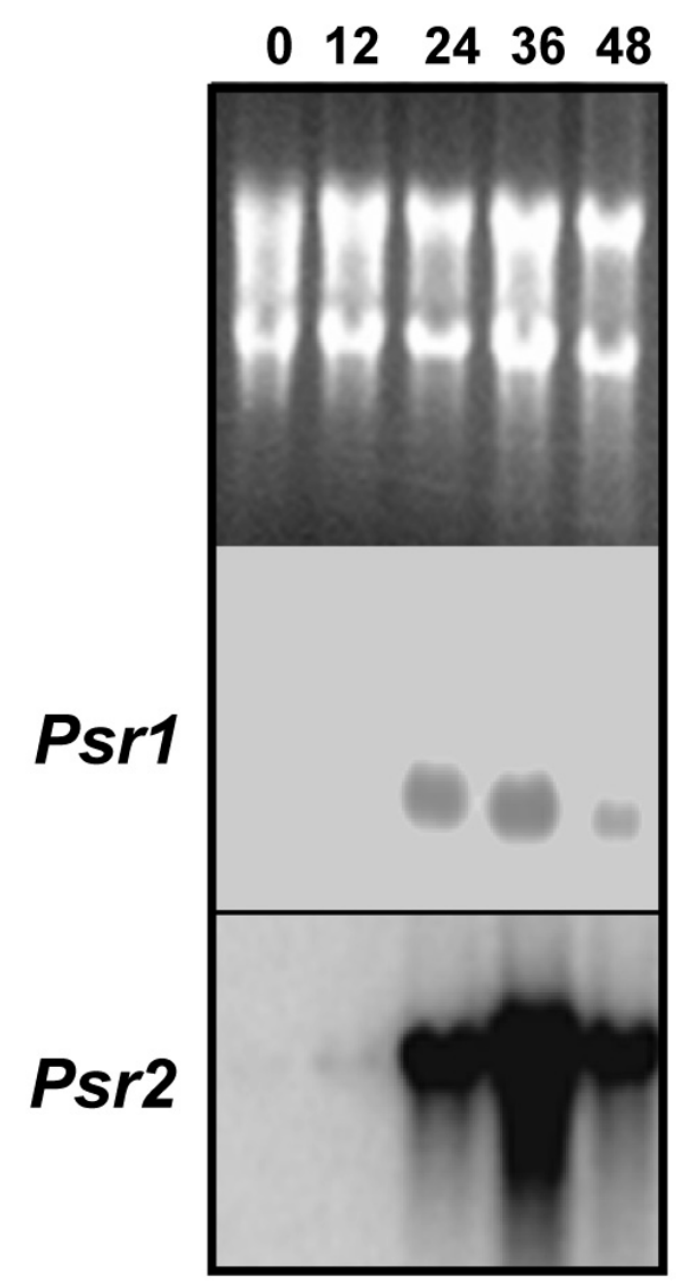

\section{Figure 6}

Time course of expression of Psrl and Psr2 Total RNA $(10 \mu \mathrm{g})$ from petals at each time point was separated on a I. $2 \%$ agarose gel containing formaldehyde, transferred to Genescreen membranes, and hybridized to probes of cDNA inserts. rRNA panel is a loading control stained with ethidium bromide. Numbers indicate HACP.

cells to determine the subcellular location of the GFP fusion by immunoblot analysis. We prepared chloroplast, mitochondria, peroxisome, and tonoplast fractions and probed with an anti-GFP antibody and appropriate controls for our fractionation (Fig. 11). GFP signal was detected only in the tonoplast membrane (Fig. 11). The PiCYP74C9::GFP fusion exhibits a higher mobility when denatured at $50^{\circ} \mathrm{C}$ vs. $100^{\circ} \mathrm{C}$ (Fig. 11). Proteins were treated at the lower temperature treatment (shown in Fig. 11B) because the control tonoplast marker, vacuolar pyrophosphatase, is unstable at high temperature [51].

\section{Discussion}

The identification of macromolecules that increase in abundance during petal senescence is critical for our understanding of this process. Although a number of genes have been cloned that are highly expressed in senescing petals, the signal transduction pathways remain poorly understood. In addition to PiCYP74C9, a second highly induced known gene that we also identified during our study encodes ACC oxidase, which is involved in ethylene biosynthesis. The identification of ACC oxidase is not surprising, given that ethylene is known to be important in signaling petunia floral senescence $[52,53]$. The ethylene peak in $P$. inflata petal tissue starts from 18 HACP and peaks at 24 HACP [54]. This ethylene surge lags behind the up-regulation of ACC oxidase mRNA (Psr1) which shows up-regulation starting after 12 HACP (Fig. 6 ). This timing supports the theory that de novo synthesis of ethylene is required for the increased ethylene level.

Our previous study [6] showed that the total amount of RNA decreased about $50 \%$ at 24 HACP. Up to 36 HACP, the steady-state levels of the Psr1 and Psr2 transcripts continue to increase despite collapse of the floral shape and decrease in total RNA and protein contents, suggesting that Psr 1 and Psr 2 transcripts are either continuously transcribed or protected from the large-scale degradation of RNA in the senescing petal. This indicates active regulation of petal senescence by the plant.

Both ethylene and MEJA induced expression of Psr2 in unpollinated petals. Jasmonates also evidently play a role in the regulation of the gene encoding LeAOS3, the CYP74C member most closely related to PiCYP74C9, as expression of LeAOS3 in roots did not occur in a tomato mutant insensitive to jasmonates [26]. LeAOS3 transcripts were found in germinating seedlings and roots but not cotyledons, mature leaves, stems, nor flower buds; evidently senescing tissue was not tested [26]. Our data suggests that it will be worthwhile to examine the expression of the genes encoding LeAOS3 and the similar StAOS3 protein in stressed tissues to find out whether all of these synthases are upregulated during programmed cell death. Likewise, it will be interesting to determine whether or not LeAOS3 and StAOS3 are targeted to the tonoplast.

P450 enzymes constitute a superfamily of enzymes that are important in the oxidative, peroxidative, and reductive metabolism of numerous endogenous compounds (reviewed in [54-56]). The CYP74 family does not require molecular oxygen, instead the oxygen is provided by the hydroperoxide substrates. There are a number of products and derivatives of the CYP74 enzymatic reactions, and some of these have well-known signaling properties while others are of unknown biological activity (Fig. 12). At present the family is divided into four sub-groups, but as 

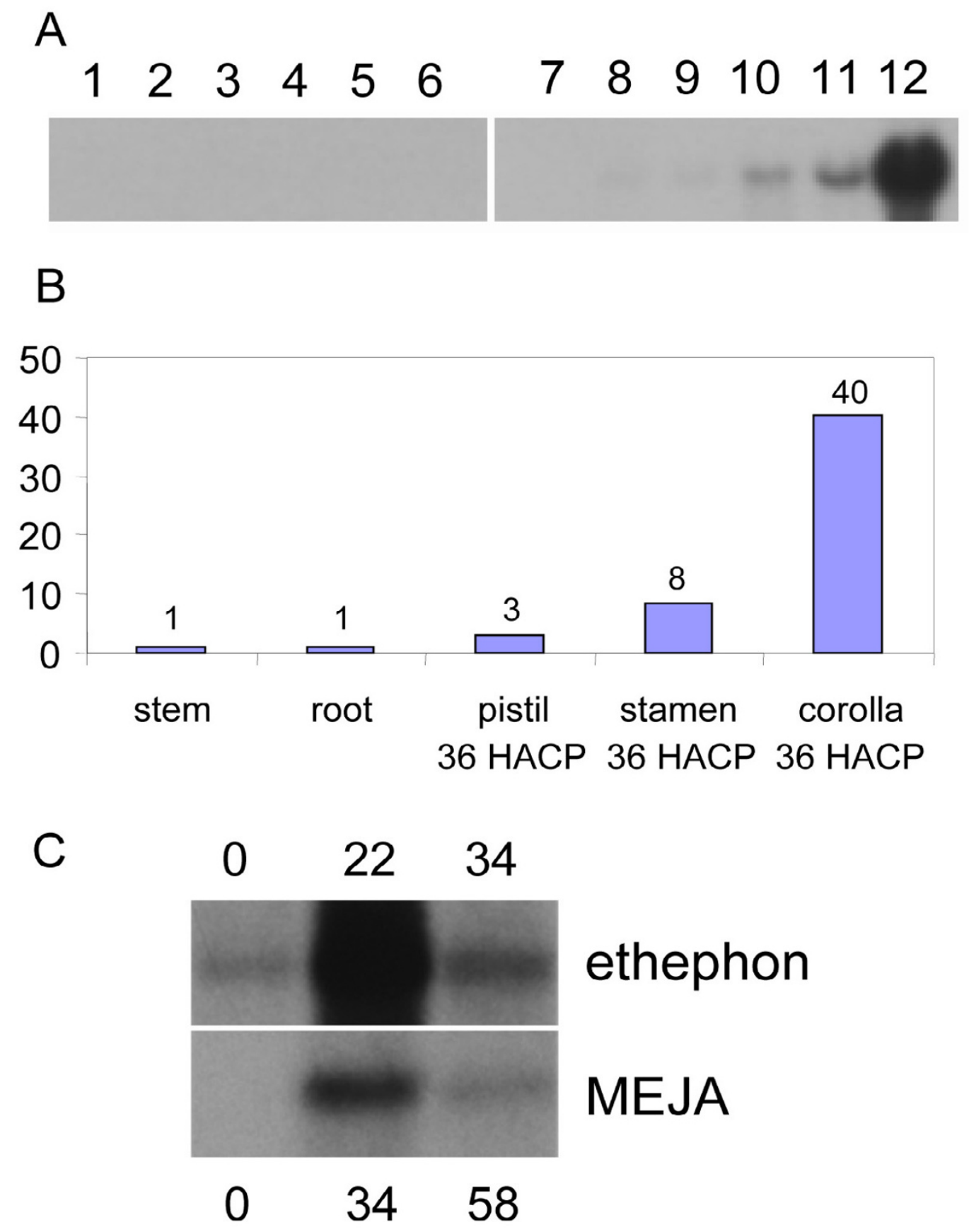

\section{Figure 7}

Tissue-specificity and developmental regulation of expression of Psr2. Total RNA ( $10 \mu \mathrm{g}$ ) from different tissues was fractionated on a $1.2 \%$ agarose gel containing formaldehyde and probed with a Psr2 probe. (A) Lane I, petal (one day before opening); lane 2, corolla (just opened flowers); lane 3, corolla tube (just opened flowers); lane 4, anther (tapetum degeneration stage); lane 5, pistil (tapetum degeneration stage); lane 6, anther (one day before opening); lane 7, healthy leaf; lane 8, stem; lane 9, root; lane 10, pistil (36 HACP); lane II, stamen (36 HACP); lane I2, petal (36 HACP). (B) Densitometry measurements of lanes 7 to 12 relative to the stem signal. (C) RNA blots from petal tissue treated with I mM ethephon, at 0, 22, and 34 hours after treatment or with $50 \mu \mathrm{M}$ methyl jasmonates (MEJA) at 0,34 , and 58 hours after treatment. Shortly before 0 time, the flower petals had opened. 


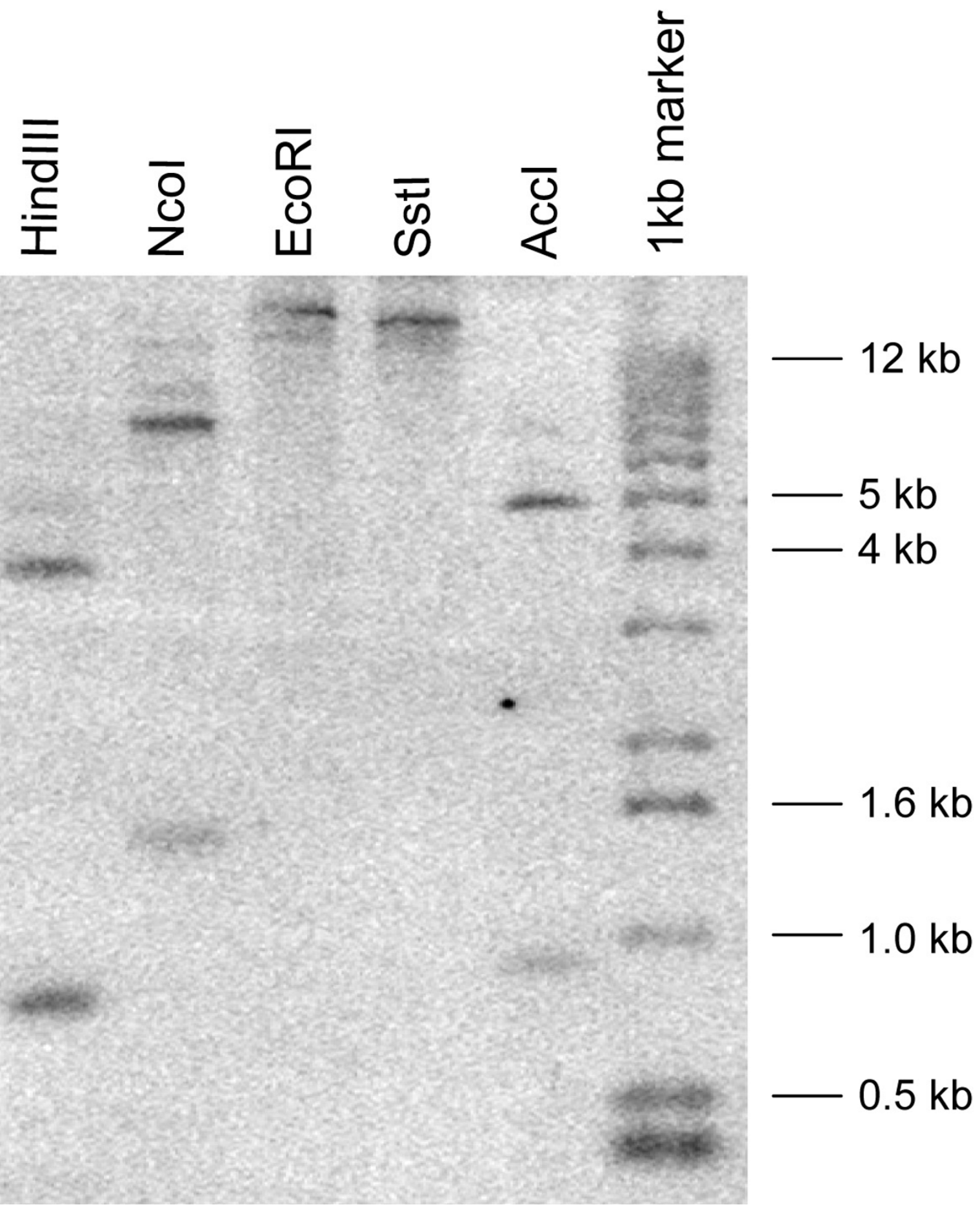

Figure 8

DNA blot analysis of Psr2. Equal amounts of $P$. inflata genomic DNA were digested with restriction enzymes, separated on a I\% agarose gel, transferred to a nylon membrane, and hybridized with Psr2 cDNA. Among the enzymes used, Hindlll, Ncol, and Accl have one cleavage site in Psr2. EcoRI and Sstl have no cleavage sites in Psr2. 


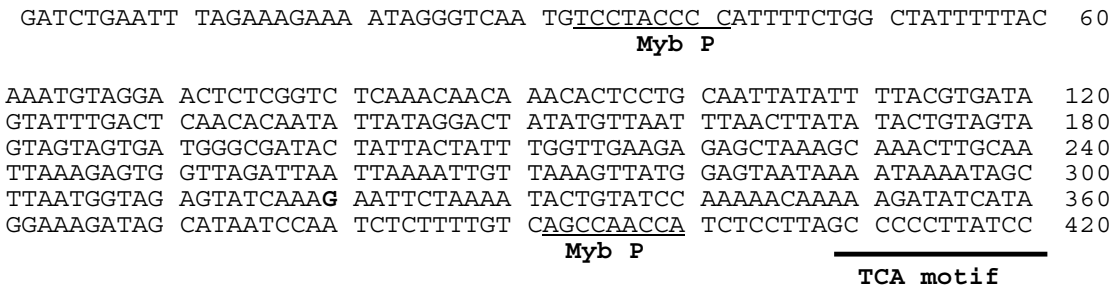

Figure 9

The genomic sequence of the promoter region of Psr2 [Genbank: DQ35I289]. Putative cis-acting elements are underlined and labeled. The transcription start site $(A)$ is labeled $+I$. 


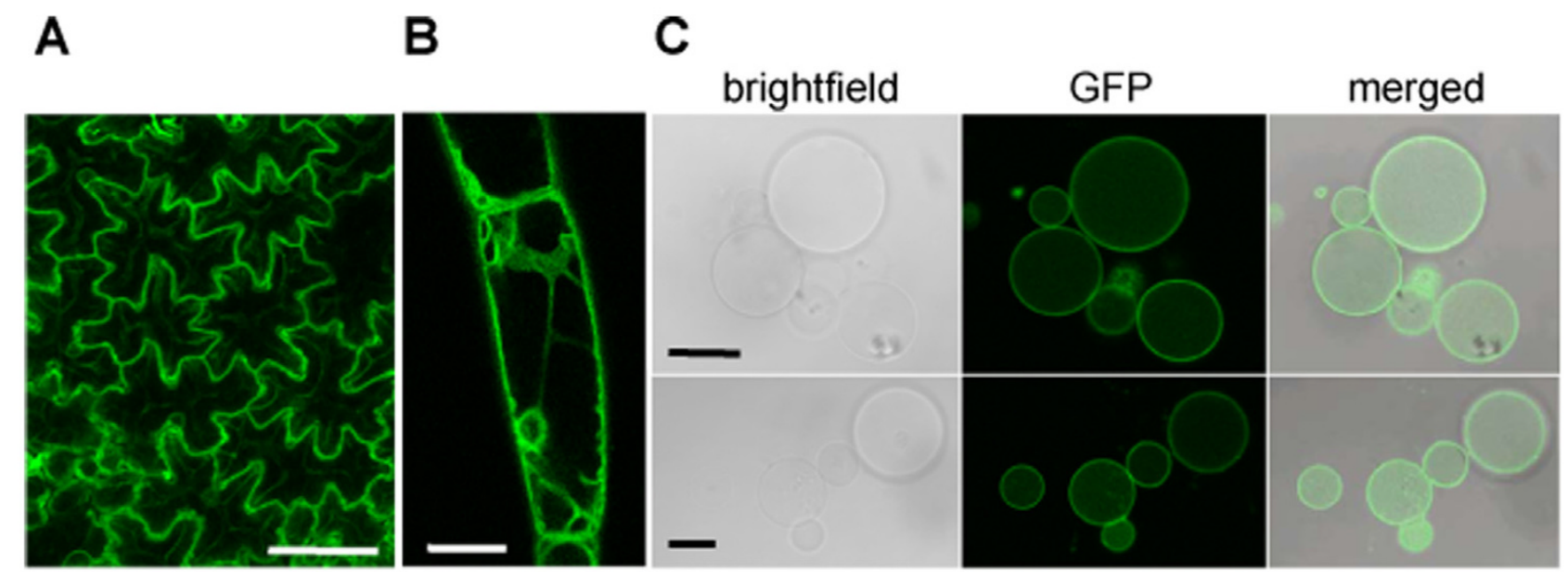

Figure 10

Subcellular localization of PiCYP74C9::GFP protein assessed by microscopy. A) epidermal cells. B, trichome cells. C, purified vacuoles. GFP signal is evident in the tonoplast. Bars $=20 \mu \mathrm{m}$.

more becomes known about these unusual P450s, perhaps five sub-groups will be warranted. The HPL and AOS activities on 13-hydroperoxides have been characterized in more species than the 9-hydroperoxides-preferring enzymes and clearly fall into two sub-families (Fig 5). Neither CYP74C nor CYP74D enzymes have been found in the Arabidopsis genome; indeed, at present, the AOS CYP74C enzymes are known only in Solanaceae (Fig. 5), while the HPL CYP74C enzymes have not yet been described in this family. As well as enzyme activity, future analysis may reveal whether intracellular localization also differs between sub-families and between the HPL vs. AOS CYP74C proteins.

Lipoxygenases, which act upon lipids to produce the hydroperoxide substrates utilized by CYP74 cytochrome P450s (Fig. 12), have been found in a variety of locations within the plant cell, including the vacuole $[57,58]$. Some CYP74 proteins have an N-terminal chloroplast transit peptide and are associated with the chloroplast. In flax, tomato, and barley, the transit sequence has been shown to be functional as targeting signal for certain AOS proteins to chloroplasts [48-50]. A tomato AOS was targeted to the outer chloroplast envelope membrane, while an HPL was targeted to the inner membrane [48]. However, other CYP74 members exist with no predictable location and await experimental determination. For example, only one of four predicted AOS genes in rice carries a putative chloroplast transit sequence [59]. Not all CYP74A members are found in the chloroplast; the guayule CYP74C AOS (PaAOS) is associated with rubber particles [60].
Our results indicate that PiCYP74C9::GFP expressed in tobacco leaves is localized in tonoplasts but not in chloroplasts, mitochondria, nor peroxisomes. We presume that PiCYP74C9 is also located in the tonoplast in petunia during petal senescence. To our knowledge, this is the first example of a CYP74 subfamily member to be localized in the tonoplast. Both N-terminal [61] and C-terminal [47] GFP fusions with known tonoplast proteins have resulted in GFP labeling of the tonoplast. None of the computer programs we tested (Predotar, TargetP, Psort) predicted PiCYP74C9 to be located in either plastids, mitochondria, or the secretory pathway.

The tonoplast localization of PiCYP74C9 is intriguing given recent information about the important role of the vacuole in programmed cell death. While it has been known for some time that caspase activity is involved in both developmental and hypersensitive response cell death, only recently has the vacuolar processing enzyme been shown to exhibit caspase activity that is important for the execution phase of several types of PCD [62-64]. During senescence, cell contents can be recycled by digestion in vacuoles in the process of autophagy [65]. In some types of developmental programmed cell death, including petal senescence, the final stages coincide with ultrastructural changes and permeabilization of the tonoplast and other membranes (reviewed in $[5,16,66]$ ). Confirmation of the allene oxide synthase activity of PiCYP74C9 on 9hydroperoxides and identification of the products may give insights into the role of this protein in petal senescence. Future analyses of the PiCYP74C9 protein should also reveal the significance of its compartmentation in the tonoplast. 

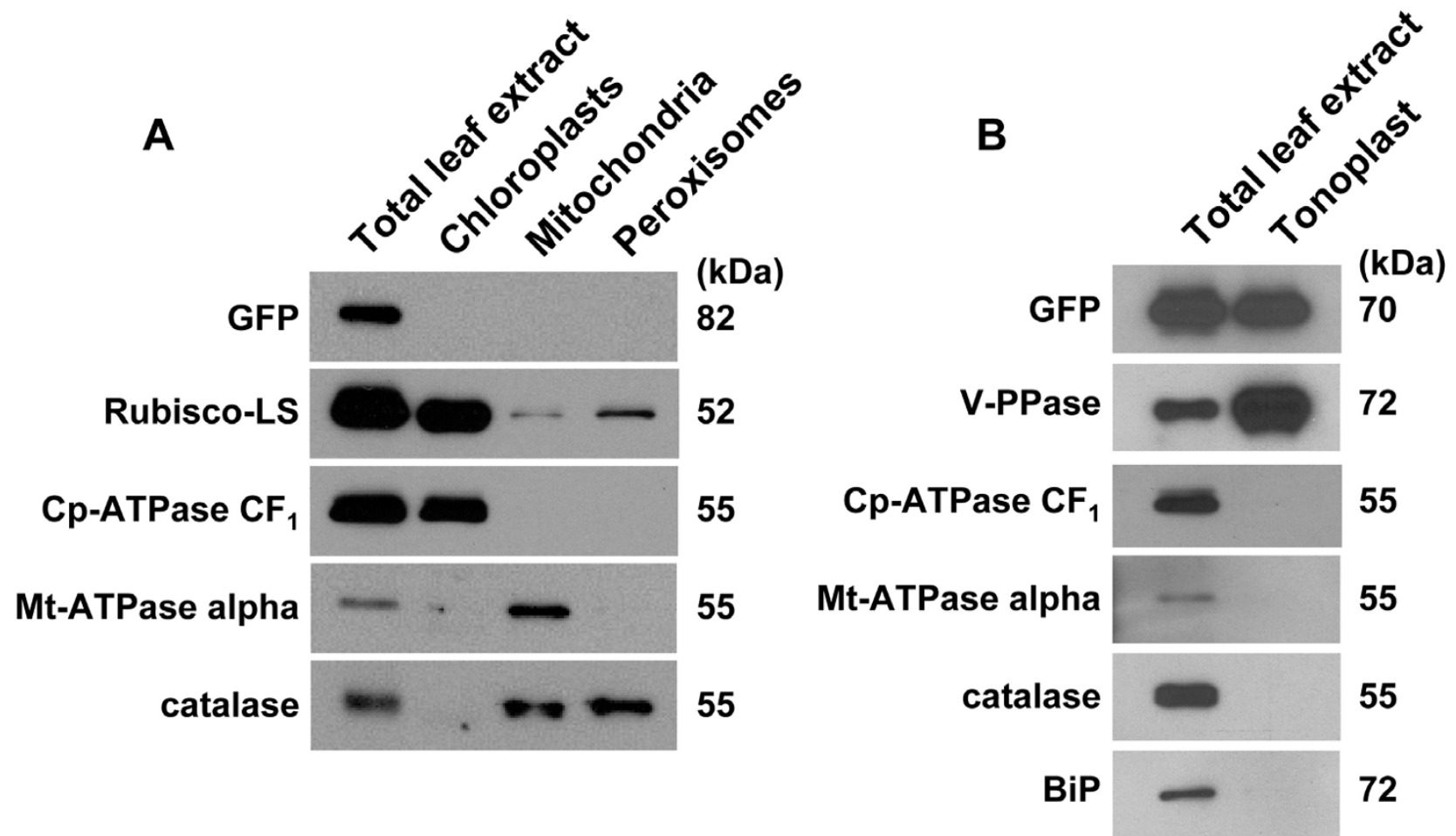

Figure I I

Subcellular localization of PiCYP74C9::GFP protein by cell fractionation and immunoblot analysis. Leaves of a transgenic tobacco plant expressing the PiCYP74C9::GFP fusion protein were fractionated into total leaf extract, chloroplasts, mitochondria, peroxisomes, and tonoplast. Proteins were separated on a 12.5\% SDS-polyacrylamide gel, transferred to a nitrocellulose membrane, and probed with antibodies against GFP, the large subunit of Rubisco (Rubisco-LS), coupling factor I of chloroplastic ATPase (Cp-ATPase $\mathrm{CF}_{1}$ ), mitochondrial ATPase alpha subunit (Mt-ATPase alpha), catalase, vacuolar membrane proton-translocating inorganic pyrophosphatase (V-PPase), and binding protein (BiP). Protein amounts loaded were $5 \mu \mathrm{g}$ in $\mathrm{A}$ or $2.5 \mu \mathrm{g}$ in B for total leaf extracts, $3 \mu \mathrm{g}$ for chloroplasts, $0.3 \mu \mathrm{g}$ for mitochondria and peroxisomes, and $0.15 \mu \mathrm{g}$ for tonoplast. Sample denaturation with SDS was done at $100^{\circ} \mathrm{C}$ for $3 \mathrm{~min}$ in $\mathrm{A}$ and at $50^{\circ} \mathrm{C}$ for $20 \mathrm{~min}$ in $\mathrm{B}$.

\section{Conclusion}

By the technique of differential display, we have identified a cytochrome P450 that is expressed at a level 40 times greater in senescing petals than in vegetative tissue. Upregulation occurs in response to compatible pollination, ethylene treatment, or jasmonate treatment. The petunia gene encodes a protein highly similar to a tomato CYP74C protein known to exhibit allene oxide synthase activity, preferentially on 9-hydroperoxides. Both a complete cDNA and genomic sequence of this single-copy gene have been obtained The promoter region of the petunia gene exhibits several motifs found in stress-responsive genes as well as binding sites for a petunia transcription factor. A C-terminal GFP fusion protein was located in the tonoplast, a compartment where CYP74 members have not previously been detected. Phylogenetic analysis indicates that the CYP74C subfamily may warrant future divi- sion into two groups, as more information becomes available about AOS and HPL enzymes acting on 9hydroperoxides.

\section{Methods}

Plant materials, growth, and pollination

Two different $P$. inflata populations bearing different $S$ alleles can be used to pollinate each other. A line termed $P$. inflata-1 was derived from seed originally received from Ken Sink (Michigan State). The other population, termed P-S-14, was provided by D. Maizonnier (Dijon, France), who obtained it from a South American source. Plants were grown at $23^{\circ} \mathrm{C}$ under $16 \mathrm{hr}$ daylight and $8 \mathrm{hr}$ darkness. The compatibility of P-S-14 pollen on P. inflata-1 was confirmed by seed production, while self-pollination of $P$. inflata- 1 flowers did not result in seed set. Pollen from P-S-14 was used to pollinate P. inflata-1 on the day 


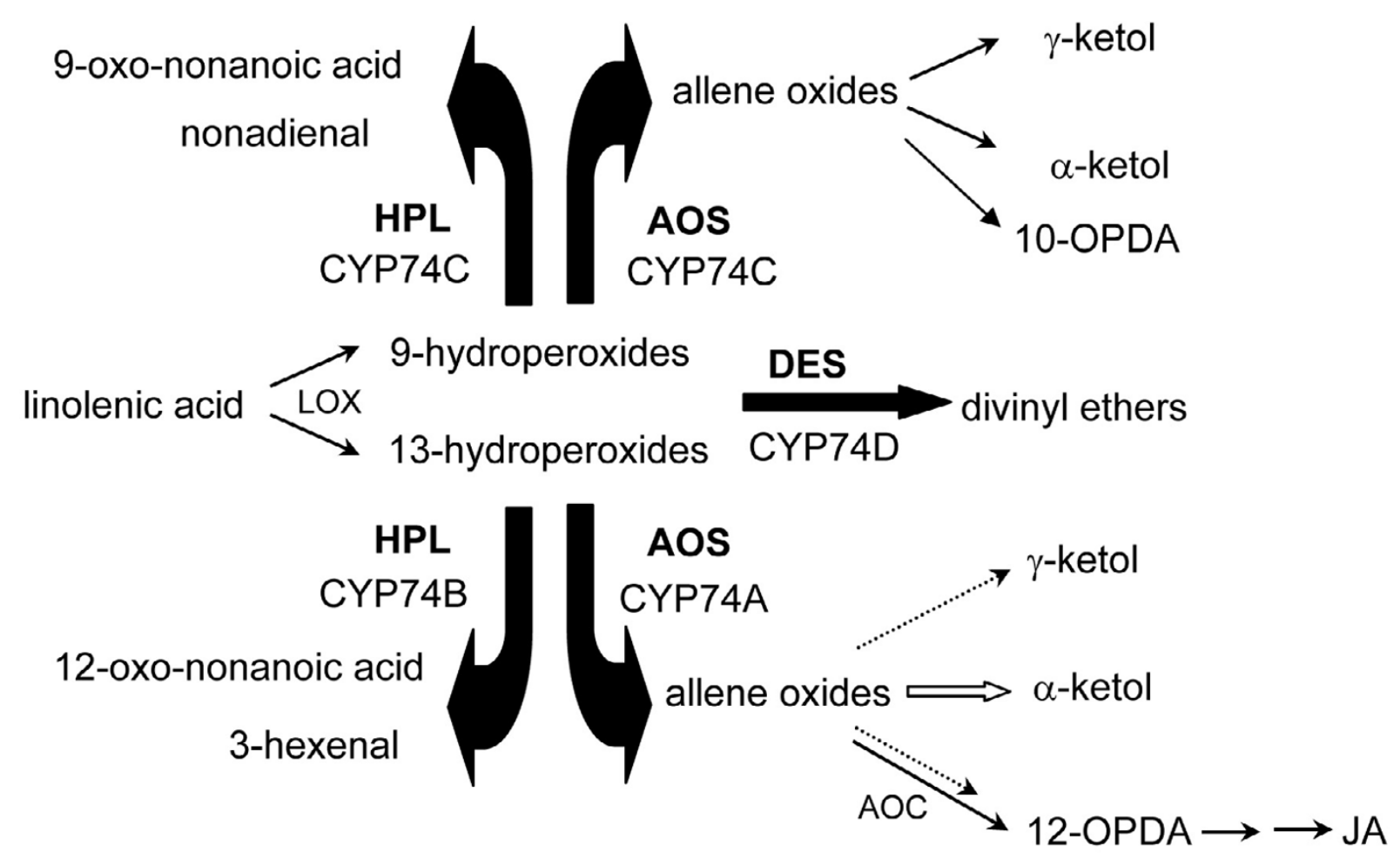

Figure 12

Diagram of enzymatic activities of CYP74 family members (as reviewed in [26,85,86]. LOX: lipoxygenase. AOC: allene oxide cyclase OPDA: oxo-phytodienoic acid.

of flower opening. At pollination, the five stamens were removed from $P$. inflata-1 flowers to reveal the stigma and to avoid incompatible pollination.

Transgenic tobacco cv. Petit Havana plants containing the PiCYP74C9::GFP fusion that were used for cellular fractionation were grown in a growth room at $23^{\circ} \mathrm{C}$ under 16 hr light and $8 \mathrm{hr}$ darkness for about one month before organelle isolation. For fluorescence microscopy observations, transgenic tobacco plants containing the PiCYP74C9::GFP fusion were grown in a greenhouse under natural illumination. Both GFP genes were under the control of the $35 \mathrm{~S}$ promoter with AMV translation enhancer [46] in the PGTPV-Kan vector [67]. Transgenic tobacco plants were produced as described by Kwok and Hanson [68].

\section{Chemical treatments of detached flowers}

Flowers were cut at the pedicel the day of opening. Twelve flowers were used in each treatment with pedicel placed in the chemical solution held in a 24 -well tissue culture plate (Northeast Container Corporation, Dover, NH). The plate was left in the greenhouse with $16 \mathrm{hr}$ light and $8 \mathrm{hr}$ darkness. The stock solution for ethephon (Sigma Chemical, St. Louis, MO) was $1 \mathrm{mM}$ in $\mathrm{ddH}_{2} \mathrm{O}$. The stock solution for MEJA (Bedoukian Research Inc., Danbury, CT) was $100 \mathrm{mM}$ in 95\% ethanol. Stock solutions were kept at $80^{\circ} \mathrm{C}$. The working solution was diluted from the stock solution in $\mathrm{ddH}_{2} \mathrm{O}$ before use.

\section{RNA isolation and RNA blot analysis}

Total RNA was extracted with TRIZOL reagent according to the manufacturer's instruction (GIBCO BRL). RNA amounts were determined by $\mathrm{OD}_{260}$. RNA electrophoresis (10 $\mu \mathrm{g}$ total RNA per lane) was carried out in formaldehyde denaturing gels as described (Sambrook et al. 1989), but the concentration of formaldehyde in the gel and running buffer was reduced to $0.7 \mathrm{M}$. RNA was transferred to Genescreen membrane (NEN Research Products, Boston, $\mathrm{MA}$ ) in 20xSSC and hybridized at $65^{\circ} \mathrm{C}$ overnight in Church buffer (250 mM NaPO4, pH 7.2, 7\% SDS, 1\% BSA, $1 \mathrm{mM}$ EDTA). Probe labeling was done with the random priming labeling kit DECAprimeII (Ambion, Austin, 
TX). After overnight hybridization, filters were washed twice with $0.2 \mathrm{xSSC} / 0.1 \%$ SDS at $65^{\circ} \mathrm{C}$.

\section{Differential display}

Total RNA was extracted from 10 petals at 0,24 , and 36 HACP using TRIZOL reagent with the following modification from standard protocol. Before isopropanol precipitation, two rounds of ether extraction were added. After isopropanol precipitation, RNA was dissolved in $\mathrm{ddH}_{2} \mathrm{O}$ and precipitated in the presence of $2 \mathrm{mM} \mathrm{LiCl}$ at $4{ }^{\circ} \mathrm{C}$ overnight. RNA concentration was determined by $\mathrm{A}_{260}$. For differential display, $1.5 \mu \mathrm{g}$ total RNA from 0 HACP was compared with that of 24 or 36 HACP following the instructions for differential display provided by GenHunter (Brookline, MA). Reagents used in reverse transcription were from GIBCO BRL and the PCR buffer was from GenHunter. The primers for differential display were a generous gift from Dr. Mikhail Nasrallah.

\section{DNA isolation and blot analysis}

Genomic DNA was isolated according to a modified CTAB method [69]. For DNA blot analysis, equal amounts of genomic DNA were digested with restriction enzymes, separated on a $1 \%$ agarose gel, and transferred to Hybond $\mathrm{N}^{+}$(Amersham Pharmacia). The hybridization was done as described for RNA blot analysis.

\section{cDNA library construction and screening}

Total RNA isolation was performed following a phenol/ SDS method [70] with modifications. Five grams of petals from 24 HACP or 36 HACP were ground in liquid $\mathrm{N}_{2}$ and further ground after adding $40 \mathrm{ml}$ NES buffer $(100 \mathrm{mM}$ $\mathrm{NaCl}, 5 \mathrm{mM}$ EDTA, 1\% SDS) and $20 \mathrm{ml}$ sodium acetatebuffered phenol ( $\mathrm{pH} 4.0$ ). The mixture was then homogenized with a Polytron (Brinkmann Instruments Inc., Westbury, NY) for 2 min. Messenger RNA was purified through an oligo(dT)-cellulose column (type 7) following the manufacturer's instruction (Amersham Pharmacia). Handling of the cDNA library, including construction, titering, screening, and in vivo excision, followed the manufacturer's instructions. The ZAP Express cDNA synthesis kit and ZAP Express cDNA Gigapack III gold cloning kit (Stratagene, La Jolla, CA) were used for the cDNA library construction. Starting with $5 \mu \mathrm{g}$ mRNA from senescing petals ( $2.5 \mu \mathrm{g}$ from $24 \mathrm{HACP}$ and $2.5 \mu \mathrm{g}$ from $36 \mathrm{HACP})$, a primary cDNA library with about 540,000 recombinant phage was obtained. About 25,000 primary phage were screened to clone the gene.

\section{Cellular fractionation}

Tobacco leaves were homogenized in Hepes- $\mathrm{NaOH}(\mathrm{pH}$ 7.5) containing $14 \mathrm{mM}$ 2-mercaptoethanol and protease inhibitor cocktail (Complete Mini, Roche) in a chilled mortar and pestle. The homogenate was mixed with an equal volume of SDS sample buffer consisting of $200 \mathrm{mM}$
Tris-HCl (pH 8.5), 2\% (w/v) SDS, 0.7 M 2-mercaptoethanol, and $20 \%(\mathrm{v} / \mathrm{v})$ glycerol and then it was boiled for 3 min or heated at $50^{\circ} \mathrm{C}$ for 20 min when used in comparison with tonoplast vesicles. Following microcentrifugation, the supernatant was taken for use as the whole leaf extract.

For the isolation of organelles, leaves were cut into small slices (approximately $1 \mathrm{~mm} \times 10 \mathrm{~mm}$ ) with a razor blade and homogenized in a Polytron for $2 \mathrm{sec}$ five to seven times with $5 \mathrm{ml}$ of a homogenizing buffer per gram fresh weight of leaves.

Chloroplasts were isolated from $30 \mathrm{~g}$ of leaves essential as described previously [71] except that the extraction and Percoll gradient buffer contained 2 mM EDTA instead of $10 \mathrm{mM}$ EDTA. Intact chloroplasts were collected from a green layer near the bottom of Percoll gradients, suspended in $50 \mathrm{mM}$ Hepes- $\mathrm{NaOH}$ ( $\mathrm{pH} 8.0$ ) containing 0.3 $\mathrm{M}$ mannitol and $2 \mathrm{mM}$ EDTA, and centrifuged at 3,000 $\mathrm{g}$ for $40 \mathrm{~s}$. The resulting pellet was used as the purified chloroplast fraction.

Mitochondria were isolated from $60 \mathrm{~g}$ of leaves using Percoll gradient centrifugation with $0-5 \%(\mathrm{w} / \mathrm{v})$ PVP-40 preformed gradient based on the method described by Day et al[72] with slight modifications as follows. Leaves were homogenized with a grinding buffer consisting of $25 \mathrm{mM}$ Mops-KOH (pH 7.8) containing $0.4 \mathrm{M}$ mannitol, $10 \mathrm{mM}$ Tricine, $8 \mathrm{mM}$ cysteine, $1 \mathrm{mM}$ EGTA, $1 \%(\mathrm{w} / \mathrm{v})$ PVP-40, and $0.1 \%(\mathrm{w} / \mathrm{v})$ BSA. The homogenate was passed through eight layers cheesecloth and centrifuged at 1,000 $\mathrm{g}$ for $5 \mathrm{~min}$. The supernatant was centrifuged again at $12,000 \mathrm{~g}$ for $15 \mathrm{~min}$. The pellet was washed with $25 \mathrm{mM}$ Mops-KOH (pH 7.2) containing 0.4 M mannitol and 1 mM EGTA and was suspended in the same buffer and layered on top of a solution of $28 \%(\mathrm{v} / \mathrm{v})$ Percoll in $25 \mathrm{mM}$ Mops-KOH (pH 7.2) containing $0.4 \mathrm{M}$ mannitol and $0.1 \%(\mathrm{w} / \mathrm{v})$ BSA with $0-5 \%(\mathrm{w} / \mathrm{v})$ PVP-40 preformed gradient. After centrifugation at $40,000 \mathrm{~g}$ for $45 \mathrm{~min}$, white band near the bottom of the tube was collected, suspended in $25 \mathrm{mM}$ Mops- $\mathrm{KOH}$ (pH 7.2) containing $0.4 \mathrm{M}$ mannitol and $1 \mathrm{mM}$ EGTA, and centrifuged at $12,000 \mathrm{~g}$ for $15 \mathrm{~min}$. The resulting pellet was used as the purified mitochondrial fraction.

Peroxisomes were isolated from $30 \mathrm{~g}$ of leaves based on the method described by Fukao et al. [73] as follows. Leaves were homogenized with a grinding buffer consisting of $20 \mathrm{mM}$ pyrophosphate- $\mathrm{HCl}$ (pH 7.5) containing $0.3 \mathrm{M}$ mannitol and $1 \mathrm{mM}$ EDTA. The homogenate was passed through four layers of cheesecloth. The residue was homogenized with another grinding buffer again in a similar manner. The filtrates were combined and were centrifuged at $1,500 \mathrm{~g}$ for $10 \mathrm{~min}$. The supernatant was 
centrifuged again at 10,000 $\mathrm{g}$ for $20 \mathrm{~min}$. The pellet was washed with a grinding buffer, and was suspended in $4 \mathrm{ml}$ of $10 \mathrm{mM}$ Hepes-KOH (pH 7.2) containing 0.3 M mannitol and $1 \mathrm{mM}$ EDTA and was subjected to centrifugation in Percoll. The suspension was layered on top of $5 \mathrm{ml}$ of a $60 \%(\mathrm{v} / \mathrm{v})$ and $30 \mathrm{ml}$ of a $28 \%(\mathrm{v} / \mathrm{v})$ solution of Percoll in $10 \mathrm{mM}$ Hepes-KOH (pH 7.2) containing $1 \mathrm{mM}$ EDTA and $0.3 \mathrm{M}$ raffinose and was centrifuged at $40,000 \mathrm{~g}$ for $30 \mathrm{~min}$ without deceleration. After centrifugation, $1 \mathrm{ml}$ fractions were collected by a fraction collector. The 6th fraction from the bottom, which had the highest catalase content judging from immunoblot analysis, was used as the purified peroxisome fraction.

Vacuoles were isolated from leaf protoplasts as follows. Leaves ( $15 \mathrm{~g}$ ) were cut into small slices as described above and digested with an incubation medium conainting 1.5\% Cellulase Onozuka RS, 0.4\% Macerozyme R-10, 10 $\mathrm{mM}$ Mes- $\mathrm{NaOH}$ (pH 5.6), $8 \mathrm{mM} \mathrm{CaCl}_{2}$ and $0.7 \mathrm{M}$ mannitol for $3 \mathrm{~h}$ at $30^{\circ} \mathrm{C}$ in darkness. After digestion, released protoplasts were passed through a $150-\mu \mathrm{m}$ nylon mesh and washed with $0.7 \mathrm{M}$ mannitol for three times. Protoplasts were treated with DEAE-dextran solution for the lysis and released vacuoles were separated by the discontinuous Ficoll gradient centrifugation as previously described by Asami et al. [74].

Tonoplast vesicles were isolated from $20 \mathrm{~g}$ of leaves based on the method described by Maeshima and Yoshida [75] as follows. Leaves were homogenized with a grinding buffer consisting of $50 \mathrm{mM}$ Tris-acetate ( $\mathrm{pH} 7.5$ ) containing $0.25 \mathrm{M}$ sorbitol, $2 \mathrm{mM}$ EGTA, $1 \%$ (v/v) PVP-40, $2 \mathrm{mM}$ DTT and $0.5 \mathrm{mM}$ PMSF. The homogenate was passed through four layers of cheesecloth. The filtrates were centrifuged at 3,600 $\mathrm{g}$ for $10 \mathrm{~min}$. The supernatant was centrifuged again at $120,000 \mathrm{~g}$ for $30 \mathrm{~min}$. The pellet was suspended in $15 \mathrm{ml}$ of $20 \mathrm{mM}$ Tris-acetate (pH 7.5) containing $0.5 \mathrm{M}$ sucrose, $1 \mathrm{mM}$ EGTA, $2 \mathrm{mM}$ DTT and $2 \mathrm{mM}$ $\mathrm{MgCl}_{2}$ and poured into a centrifugation tube. The suspension was overlayed with $15 \mathrm{ml}$ of $20 \mathrm{mM}$ Tris-acetate (pH 7.5) containing $0.25 \mathrm{M}$ sorbitol, $1 \mathrm{mM}$ EGTA, $2 \mathrm{mM}$ DTT and $2 \mathrm{mM} \mathrm{MgCl}_{2}$. After centrifugation at $120,000 \mathrm{~g}$ for 30 min in a Beckman $70 \mathrm{Ti}$ rotor, the interference portion was collected and diluted in a three-times volume of 20 $\mathrm{mM}$ Tris-acetate ( $\mathrm{pH} 7.5$ ) containing $0.25 \mathrm{M}$ sorbitol, 1 mM EGTA, $2 \mathrm{mM}$ DTT and $2 \mathrm{mM} \mathrm{MgCl}$. The suspension was then centrifuged at $120,000 \mathrm{~g}$ for $30 \mathrm{~min}$ and the resulting pellet was used as the tonoplast preparation.

\section{Immunoblot analysis}

Purified organelles, except tonoplast vesicles, were mixed with an equal volume of SDS sample buffer as above and then boiled for $3 \mathrm{~min}$. Tonoplast vesicles were denatured at $50^{\circ} \mathrm{C}$ for $20 \mathrm{~min}$. Protein concentration was determined by RC DC Protein Assay (Bio-Rad) based on Lowry method [76] according to the manufacturer's instruction. BSA was used as standard. Protein amounts loaded on $12.5 \%(\mathrm{w} / \mathrm{v})$ SDS-PAGE gels were $5 \mu \mathrm{g}$ for whole leaf extract, $3 \mu \mathrm{g}$ for chloroplasts, $0.3 \mu \mathrm{g}$ for mitochondria and peroxisomes, and $0.15 \mu \mathrm{g}$ for tonoplasts. Immunoblot analysis was performed by the method of Towbin et al. [77].

Antibodies used were rabbit anti-GFP antibodies (1:5,000, Molecular Probes), affinity-purified anti-large subunit of Rubisco antibodies (1:20,000; [78]) from rabbit anti-rice whole Rubisco antibodies [79] and rabbit anti-rice coupling factor 1 of chloroplastic ATPase antibodies (1:5,000; [80]), both gifts of Dr. Amane Makino; a mouse anti-maize mitochondrial ATPase alpha subunit antibody (1:200; [81]); a mouse anti-tobacco catalase monoclonal antibody purchased from Princeton University Molecular Biology Department Monoclonal Antibody Facility (1:500; [82]); anti-peptide antibody for vacuolar pyrophosphatase corresponding to the sequences HKAAVIGDTIGDPLK (putative loop XII, 1:50,000), a gift of Dr. Philip Rea [51]; and anti-binding protein, a gift of Dr. Eliot Herman (1:50,000, [83]).

\section{Microscopy}

Laser-scanning confocal and differential interference contrast microscopy was performed with a Leica TCS-SP2 confocal scanning head mounted on a Leica DMRE-7 (SDK) upright microscope equipped with a $100 \times \mathrm{HCX}$ PL APO oil immersion objective (NA $=1.40$; Leica Microsysytems Inc., Bannockburn, IL, USA). GFP was excited with the $488 \mathrm{~nm}$ line of a 4-line Argon ion laser and emission of GFP was detected between 500 and $581 \mathrm{~nm}$.

\section{Authors' contributions}

YX cloned Psr cDNAs and Psr2 genomic DNA, performed expression analyses, and regenerated transgenic plants carrying the PiCYP74C9::GFP fusion. HI fractionated cells of transgenic plants and carried out immunoblot analysis. DR made the microscopic observations. Both YX and MRH performed bioinformatic analyses and wrote the manuscript. MRH coordinated the project and edited the final manuscript, which was approved by all authors.

\section{Acknowledgements}

We thank Dr. Mikhail Nasrallah for providing differential display primers and Dr. Ikeda Seishi for instruction in differential display. We are grateful to Rainer $\mathrm{H}$. Köhler for valuable discussions and technical help, and thank Dr. Amane Makino (Tohoku University), Dr. Philip Rea (University of Pennsylvania), and Dr. Eliot Herman (USDA-ARS, Danforth Center) for gifts of antibodies. We thank Alex Wong for providing output from the PAUP program and Dr. John C. Robbins for assistance with sequence comparisons. This work was supported by a NSF/DOE/USDA training grant in Molecular Mechanisms of Plant Processes, DOE Energy Biosciences (DE FG0289ER (4030), and USDA CUAES funds. 


\section{References}

I. Nimchuk Z, Eulgem T, Holt BE, Dangl JL: Recognition and response in the plant immune system. Annual Review of Genetics 2003, 37:579-609.

2. Greenberg JT, Yao N: The role and regulation of programmed cell death in plant-pathogen interactions. Cell Microbiol 2004, 6:201-2II.

3. Beers EP, McDowell JM: Regulation and execution of programmed cell death in response to pathogens, stress and developmental cues. Curr Opin Plant Biol 200I, 4:56I-567.

4. Guo Y, Gan S: Leaf senescence: signals, execution, and regulation. Curr Top Dev Biol 2005, 7 I:83-II2.

5. Rogers HJ: Cell death and organ development in plants. Curr Top Dev Biol 2005, 71:225-26I.

6. $\mathrm{Xu}$ Y, Hanson MR: Programmed cell death during pollinationinduced petal senescence in petunia. Plant Physiol 2000 122:1323-1333.

7. Orzaez D, Granell A: DNA fragmentation is regulated by ethylene during carpel senescence in Pisum sativum. Plant Journal |997, I I:| 37-|44.

8. Yao N, Eisfelder BJ, Marvin J, Greenberg JT: The mitochondrion-an organelle commonly involved in programmed cell death in Arabidopsis thaliana. Plant J 2004, 40:596-610.

9. Stein JC, Hansen G: Mannose induces an endonuclease responsible for DNA laddering in plant cells. Plant Physiol 1999 , | 2 | :7|-79.

10. Tiwari BS, Belenghi B, Levine A: Oxidative stress increased respiration and generation of reactive oxygen species, resulting in ATP depletion, opening of mitochondrial permeability transition, and programmed cell death. Plant Physiol 2002 | 28: |27|-|28|.

II. Balk J, Leaver C]: The PETI-CMS mitochondrial mutation in sunflower is associated with premature programmed cel death and cytochrome c release. Plant Cell 200I, I3:1803-1818.

12. Kim M, Ahn JW, Jin UH, Choi D, Paek KH, Pai HS: Activation of the programmed cell death pathway by inhibition of proteasome function in plants. J Biol Chem 2003, 278:19406-194I5.

13. Curtis MJ, Wolpert TJ: The oat mitochondrial permeability transition and its implication in victorin binding and induced cell death. Plant J 2002, 29:295-3 I2.

14. Tang XY, Woodson WR: Temporal and spatial expression of I aminocyclopropane-I-carboxylate oxidase mRNA following pollination of immature and mature petunia flowers. Plant Physiol 1996, I I 2:503-5 I I.

15. Woodson WR, Park KY, Drory A, Larsen PB, Wang H: Expression of ethylene biosynthetic-pathway transcripts in senescing carnation flowers. Plant Physiol 1992, 99:526-532.

16. Rubinstein B: Regulation of cell death in flower petals. Plant Mol Biol 2000, 44:303-3/8.

17. Jones ML, Larsen PB, Woodson WR: Ethylene-regulated expression of a carnation cysteine proteinase during flower petal senescence. Plant Mol Biol 1995, 28:505-512.

18. Do YY, Huang PL: Characterization of a pollination-related cDNA from Phalaenopsis encoding a protein which is homologous to human peroxisomal acyl-CoA oxidase. Arch Biochem Biophys 1997, 344:295-300.

19. Meyer RCI, Goldsbrough PB, Woodson WR: An ethylene-responsive flower senescence-related gene from carnation encodes a protein homologous to glutathione S-transferases. Plant Mol Biol |99|, I 7:277-28|

20. Taylor CB, Bariola PA, delCardayre SB, Raines RT, Green PJ: RNS2: a senescence-associated RNase of Arabidopsis that diverged from the S-RNases before speciation. Proc Natl Acad Sci U S A 1993, 90:5118-5122.

21. Panavas T, Walker EL, Rubinstein B: Possible involvement of abscisic acid in senescence of daylily petals. J Exp Bot 1998, 49:1987-1997.

22. Peary JS, Prince TA: Floral lipoxygenase - activity during senescence and inhibition by phenidone. J Am Soc Hortic Sci 1990 , I 1 5:455-457.

23. Panavas T, Rubinstein B: Oxidative events during programmed cell death of daylily (Hemerocallis hybrid) petals. Plant Science 1998, I33:125-138.

24. Yang T, Poovaiah BW: An early ethylene up-regulated gene encoding a calmodulin-binding protein involved in plant senescence and death. J Biol Chem 2000, 275:38467-38473.
25. van Der Krol AR, van Poecke RM, Vorst OF, Voogt C, van Leeuwen W, Borst-Vrensen TW, Takatsuji H, van Der Plas LH: Developmental and wound-, cold-, desiccation-, ultraviolet-B-stressinduced modulations in the expression of the petunia zinc finger transcription factor gene ZPT2-2. Plant Physiol 1999, | 2 I: | |53-|| 62

26. Itoh A, Schilmiller AL, McCaig BC, Howe GA: Identification of a jasmonate-regulated allene oxide synthase that metabolizes 9-hydroperoxides of linoleic and linolenic acids. I Biol Chem 2002, 277:4605 I-46058.

27. Earnshaw WC: Apoptosis: lessons from in vitro systems. Trends Cell Biol 1995, 5:217-220.

28. Liang P, Pardee AB: Differential display - A general protocol. Molecular Biotechnology 1998, 10:261-267.

29. Frohman MA, Dush MK, Martin GR: Rapid production of fulllength cDNAs from rare transcripts: amplification using a single gene-specific oligonucleotide primer. Proc Natl Acad Sci U S A 1988, 85:8998-9002.

30. Song WC, Brash AR: Purification of an allene oxide synthase and identification of the enzyme as a cytochrome-P-450. Science 1991, 253:781-784.

31. Bate NJ, Sivasankar S, Moxon C, Riley JMC, Thompson JE, Rothstein SI: Molecular characterization of an Arabidopsis gene encoding hydroperoxide lyase, a cytochrome P-450 that is wound inducible. Plant Physiol 1998, I I 7:1393-1400.

32. Itoh A, Howe GA: Molecular cloning of a divinyl ether synthase. Identification as a CYP74 cytochrome P-450. J Biol Chem 200I, 276:3620-3627.

33. Szczesna-Skorupa E, Straub P, Kemper B: Deletion of a conserved tetrapeptide, PPGP, in P450 2C2 results in loss of enzymatic activity without a change in its cellular location. Arch Biochem Biophys 1993, 304:170-175.

34. Werck-Reichhart D, Bak S, Paquette S: Cytochromes P450. The Arabidopsis Book 2002: I-28.

35. Porat R, Halevy AH, Serek M, Borochov A: An increase in ethylene sensitivity following Pollination is the initial event trig. gering an increase in ethylene production and enhanced senescence of Phalaenopsis orchid flowers. Physiologia Plantarum 1995, 93:778-784.

36. Porat R, Reiss N, Atzorn R, Halevy AH, Borochov A: Examination of the possible involvement of lipoxygenase and jasmonates in pollination-induced senescence of Phalaenopsis and Dendrobium orchid flowers. Physiologia Plantarum 1995, 94:205-210.

37. Woltering EJ, Devrije T: Ethylene - a tiny molecule with great potential. Bioessays 1995, 17:287-290.

38. Coleman $\mathrm{CE}, \mathrm{Kao} \mathrm{TH}$ : The flanking R-regions of 2 Petunia inflata $\mathbf{S}$-alleles are heterogeneous and contain repetitive sequences. Plant Mol Biol I992, I 8:725-737.

39. Shinshi H, Usami S, Ohmetakagi M: Identification of an ethyleneresponsive region in the promoter of a tobacco class-I chitinase gene. Plant Mol Biol 1995, 27:923-932.

40. Maxson JM, Woodson WR: Cloning of a DNA-binding protein that interacts with the ethylene-responsive enhancer element of the carnation GSTI gene. Plant Mol Biol 1996, 3 I:75 I-759

4I. Oh SA, Lee SY, Chung IK, Lee CH, Nam HG: A senescence-associated gene of Arabidopsis thaliana is distinctively regulated during natural and artificially induced leaf senescence. Plant Mol Biol 1996, 30:739-754

42. Martin C, PazAres J: MYB transcription factors in plants. Trends in Genetics 1997, 13:67-73.

43. Solano R, Nieto C, Avila J, Canas L, Diaz I, Paz-Ares J: Dual DNA binding specificity of a petal epidermis-specific MYB transcription factor (MYB.Ph3) from Petunia hybrida. EMBO 1995, | 4: 1773-1784

44. Joshi CP: An inspection of the domain between putative TATA Box and translation start site in $\mathbf{7 9}$ plant genes. Nucleic Acids Research 1987, 1 5:6643-6653.

45. Kohler RH, Cao J, Zipfel WR, Webb WW, Hanson MR: Exchange of protein molecules through connections between higher plant plastids. Science 1997, 276:2039-2042.

46. Datla RSS, Bekkaoui F, Hammerlindl JK, Pilate G, Dunstan DI, Crosby WL: Improved high-level constitutive foreign gene-expression in plants using an AMV RNA4 untranslated leader sequence. Plant Science 1993, 94:139-149. 
47. Reisen D, Leborgne-Castel N, Ozalp C, Chaumont F, Marty F: Expression of a cauliflower tonoplast aquaporin tagged with GFP in tobacco suspension cells correlates with an increase in cell size. Plant Mol Biol 2003, 52:387-400.

48. Froehlich JE, Itoh A, Howe GA: Tomato allene oxide synthase and fatty acid hydroperoxide lyase, two cytochrome P450s involved in oxylipin metabolism, are targeted to different membranes of chloroplast envelope. Plant Physiol 2001, 125:306-317.

49. Harms K, Atzorn R, Brash A, Kuhn H, Wasternack C, Willmitzer L, Penacortes $\mathrm{H}$ : Expression of a flax allene oxide synthase cDNA leads to increased endogenous jasmonic acid (JA) levels in transgenic potato plants but not to a corresponding activation of JA-responding genes. Plant Cell 1995, 7:1645-1654.

50. Maucher H, Hause B, Feussner I, Ziegler J, Wasternack C: Allene oxide synthases of barley (Hordeum vulgare cv. Salome): tissue specific regulation in seedling development. Plant Journa 2000, $21: 199-213$

5I. Rea PA, Britten CJ, Sarafian V: Common identity of substratebinding subunit of vacuolar $\mathrm{H+}$-translocating inorganic pyrophosphatase of higher plant cells. Plant Physiol 1992 100:723-732.

52. Jones ML, Chaffin GS, Eason JR, Clark DG: Ethylene-sensitivity regulates proteolytic activity and cysteine protease gene expression in petunia corollas. J Exp Bot 2005, 56:2733-2744.

53. Langston BJ, Bai S, Jones ML: Increases in DNA fragmentation and induction of a senescence-specific nuclease are delayed during corolla senescence in ethylene-insensitive (etrl-I) transgenic petunias. J Exp Bot 2005, 56:15-23.

54. Singh $A$, Evensen $K B$, Kao $T H$ : Ethylene synthesis and floral senescence following compatible and incompatible pollinations in Petunia inflata. Plant Physiol 1992, 99:38-45.

55. Schuler MA, Werck-Reichhart D: Functional genomics of P450s. Annual Review of Plant Biology 2003, 54:629-667.

56. Nelson DR: Cytochrome $\mathbf{P} \mathbf{4 5 0}$ and the individuality of species. Archives of Biochemistry and Biophysics 1999, 369:1-10

57. Fischer AM, Dubbs WE, Baker RA, Fuller MA, Stephenson LC, Grimes HD: Protein dynamics, activity and cellular localization of soybean lipoxygenases indicate distinct functional roles for individual isoforms. Plant J 1999, 19:543-554.

58. Tranbarger TJ, Franceschi VR, Hildebrand DF, Grimes HD: The soybean 94-kilodalton vegetative storage protein is a lipoxygenase that is localized in paraveinal mesophyll cell vacuoles. Plant Cell I99I, 3:973-987.

59. Haga K, lino M: Phytochrome-mediated transcriptional upregulation of allene oxide synthase in rice seedlings. Plant Cell Physiol 2004, 45:119-128.

60. Pan Z, Durst F, Werck-Reichhart D, Gardner HW, Camara B, Cornish K, Backhaus RA: The major protein of guayule rubber particles is a cytochrome $\mathbf{P 4 5 0}$. Characterization based on cDNA cloning and spectroscopic analysis of the solubilized enzyme and its reaction products. I Biol Chem 1995, 270:8487-8494

6I. Uemura T, Yoshimura SH, Takeyasu K, Sato MH: Vacuolar membrane dynamics revealed by GFP-AtVam3 fusion protein. Genes Cells 2002, 7:743-753.

62. Kuroyanagi M, Yamada K, Hatsugai N, Kondo M, Nishimura M, HaraNishimura I: Vacuolar processing enzyme is essential for mycotoxin-induced cell death in Arabidopsis thaliana. J Biol Chem 2005, 280:329|4-32920.

63. Hara-Nishimura I, Hatsugai N, Nakaune S, Kuroyanagi M, Nishimura $M$ : Vacuolar processing enzyme: an executor of plant cell death. Curr Opin Plant Biol 2005, 8:404-408.

64. Lam E: Vacuolar proteases livening up programmed cell death. Trends Cell Biol 2005, I 5: I 24-127.

65. Thompson AR, Vierstra RD: Autophagic recycling: lessons from yeast help define the process in plants. Curr Opin Plant Biol 2005 8:165-173.

66. van Doorn WG, Woltering EJ: Many ways to exit? Cell death categories in plants. Trends Plant Sci 2005, I 0: I I 7-I 22

67. Becker D, Kemper E, Schell J, Masterson R: New plant binary vectors with selectable markers located proximal to the left $T$ DNA border. Plant Mol Biol 1992, 20: I I 95- I I 97.

68. Kwok EY, Hanson MR: GFP-labelled Rubisco and aspartate aminotransferase are present in plastid stromules and traffic between plastids. J Exp Bot 2004, 55:595-604.
69. Fulton TM, Chunwongse J, Tanskley SD: Microprep protocol for extraction of DNA from tomato and other herbaceous plants. Plant Mol Biol Rep 1995, I 3:207-209.

70. Sambrook J, Fritsch EF, Maniatis T: Molecular cloning: A laboratory manual, 2nd Edn. Cold Spring Harbor, NY, Cold Spring Harbor Laboratory Press; 1989.

7I. Hegeman CE, Hayes ML, Hanson MR: Substrate and cofactor requirements for RNA editing of chloroplast transcripts in Arabidopsis in vitro. Plant J 2005, 42: I24-I 32.

72. Day DA, Neuburger M, Douce R: Biochemical chalacterization of chlorophyll-free mitochondria from pea leaves. Aust J Plant Physiol 1985, I 2:219-228.

73. Fukao $\mathrm{Y}$, Hayashi M, Nishimura M: Proteomic analysis of leaf peroxisomal proteins in greening cotyledons of Arabidopsis thaliana. Plant and Cell Physiology 2002, 43:689-696.

74. Asami S, Haranishimura I, Nishimura M, Akazawa T: Translocation of photosynthates into vacuoles in spinach leaf protoplasts. Plant Physiol 1985, 77:963-968.

75. Maeshima M, Yoshida S: Purification and properties of vacuolar membrane proton-translocating inorganic pyrophosphatase from mung bean. J Biol Chem 1989, 264:20068-20073.

76. Lowry OHRNJFALRRJ: Protein measurement with the folin phenol reagent. I Biol Chem I95I, 193:265-275.

77. Towbin H, Staehelin T, Gordon J: Electrophoretic transfer of proteins from polyacrylamide gels to nitrocellulose sheets: procedure and some applications. Proc Natl Acad Sci U S A 1979 76:4350-4354.

78. Ishida H, Nishimori $Y$, Sugisawa M, Makino A, Mae T: The large subunit of ribulose-I,5-bisphosphate carboxylase/oxygenase is fragmented into 37-kDa and I6-kDa polypeptides by active oxygen in the lysates of chloroplasts from primary leaves of wheat. Plant Cell Physiol 1997, 38:47 I-479.

79. Makino A, Mae T, Ohira K: Photosynthesis and ribulose I,5bisphosphate carboxylase in rice leaves - changes in photosynthesis and enzymes involved in carbon assimilation from leaf development through senescence. Plant Physiol 1983, 73:1002-1007.

80. Hidema J, Makino A, Mae T, Ojima K: Photosynthetic characteristics of rice leaves aged under different irradiances from full expansion through senescence. Plant Physiol I99।, 97:| 287-I 293.

81. Conley CA, Hanson MR: Tissue-specific protein expression in plant mitochondria. Plant Cell |994, 6:85-91.

82. Collings DA, Harper JDI, Marc J, Overall RL, Mullen RT: Life in the fast lane: actin-based motility of plant peroxisomes. Can J Bot 2002, 80:430-441.

83. Kalinski A, Rowley DL, Loer DS, Foley C, Buta G, Herman EM: Binding-protein expression Is subject to temporal, developmental and stress-induced regulation in terminally differentiated soybean organs. Planta 1995, 195:611-621.

84. Swofford D: PAUP*. Phylogenetic analysis using parsimony (*and other methods). 4th edition. Sunderland, Mass., Sinauer Associates; 2002.

85. Howe GA, Schilmiller AL: Oxylipin metabolism in response to stress. Curr Opin Plant Biol 2002, 5:230-236.

86. Feussner I, Wasternack C: The lipoxygenase pathway. Annu Rev Plant Biol 2002, 53:275-297.

Publish with Biomed Central and every scientist can read your work free of charge

"BioMed Central will be the most significant development for disseminating the results of biomedical research in our lifetime. "

Sir Paul Nurse, Cancer Research UK

Your research papers will be:

- available free of charge to the entire biomedical community

- peer reviewed and published immediately upon acceptance

- cited in PubMed and archived on PubMed Centra

- yours - you keep the copyright
BioMedcentral 